InnOvaciOnes de NegOciOs 18(35):

(C) 2021 UANL, Impreso en México (ISSN: 2007-1191)

Recepción: 30 de noviembre 2020 Aceptación: 7 de enero 2021

\title{
Business success factors within business incubators, validation of the research tool (Factores de éxito empresarial dentro de las incubadoras de empresas, validación de la herramienta de investigación)
}

\author{
Carlos Landeros García ${ }^{1}$, María Mayela Terán Cazares ${ }^{2}$ \&, Mónica \\ Blanco Jiménez ${ }^{3}$ \\ Universidad Autónoma de Nuevo León, Facultad de Contaduría Pública y \\ Administración \\ carlos.landeros.garcia@gmail.com 1, mayela.teran@gmail.com 2, \\ moniblancoj77@hotmail.com ${ }^{3}$
}

\begin{abstract}
The importance that the development of Entrepreneurs in business Incubators has been having has caused this investigation to be carried out. In its first stage, it consists in the theoretical review of the factors that give entrepreneurs a competitive advantage in Business Success such as: Coaching, Business Linking, Digital Social Networks and the Entrepreneur Profile. Therefore, the theoretical justification of these factors and the construction and validation of the instrument are presented. A questionnaire of 51 questions was made and to test its reliability it was applied to 30 study subjects. Using the SPSS, the instrument was validated with Cronbach's alpha factors that show reliable values between .700 and .900 and a final questionnaire was obtained with 46 questions. This work provides a theoretical and methodological contribution to support business success.
\end{abstract}

Keywords: Business incubators, Entrepreneurship, Coaching, Business Linking, Digital social network and Entrepreneur profile.

JEL: M00, M10, M13

Resumen: La importancia que ha tenido el desarrollo de emprendedores en las Incubadoras de negocios ha hecho que se lleve a cabo esta investigación. En su primera etapa, consiste en la revisión teórica de los factores que otorgan

Business success factors within business incubators 
a los emprendedores una ventaja competitiva en el Éxito Empresarial tales como: Coaching, Business Linking, Redes Sociales Digitales y el Perfil Emprendedor. Por tanto, se presenta la justificación teórica de estos factores y la construcción y validación del instrument de medición. Se realizó un cuestionario de 51 preguntas para probar su confiabilidad aplicandolo a 30 sujetos de estudio. Mediante el software SPSS se validó el instrumento con factores alfa de Cronbach que arrojan valores fiables entre .700 y .900 , teniendo como resultado un cuestionario final de 46 preguntas. Este trabajo proporciona un aporte teórico y metodológico para apoyar el éxito empresarial.

\title{
Introduction
}

Mexico takes 75 ranks in place from a total number of 137 countries evaluated for their entrepreneurial activity, according to the data supplied by the Global Entrepreneurship Development Institute. However, compared with the previous year, there was a four-step setback in the evaluation, making the need for entrepreneurial support clear in all stages.

In recent years, the global importance of entrepreneurship has increased due to it being regarded as one of the factors that influence financial development in countries (Barrientos Inostroza, 2016). One of the sources for measuring countries' development or growth is through their gross domestic product, which according to the Instituto Nacional de Estadística y Geografía (INEGI) (2019), Mexico was about 18,552,607 millions of pesos for the first quarter of 2019. According to the Comisión Nacional para la Protección y Defensa de los Usuarios de Servicios (2019), there are more than 4 million micro, small, and medium enterprises in Mexico. They are considered the backbone of Mexican economy since they generate $72 \%$ of total employment and $52 \%$ of the country's GDP. However, of the total number of MSMEs in the country, $97 \%$ are micro enterprises and the remaining $3 \%$ are small and medium enterprises. Based on the financial census 2014, it is estimated that micro enterprises generated nearly 7.27 thousand millions, and of the 29 thousand millions of busy personal more than a 21 thousand million employed personnel have been working in this type of business, thus establishing the importance of micro enterprises.

\author{
Landeros, C.; Terán, M. \& Blanco, M.
}


The existing connection between enterprises and entrepreneurship is due to the entrepreneurs, since they are the ones who conceive the business opportunity, develop it, and put it into service. Since the entrepreneur is a key figure for the development of new financial units, business incubators were created to enable, through several support programs, the survival and growth of enterprises during their early years, with consolidation being their main goal (Peña-Vinces, Bravo, Álvarez, \& Pineda, 2011).

Although the first business incubator was created in 1957 the New York city by Joseph Mansuco of as a source for the generation of employment and support for new business ventures (Guceri-Ucar, 2016), the concept is recent in Mexico, with the first incubators introduced in. 2000. At the end of 2018, there were 179 basic and 79 high-impact incubators (INADEM, 2018). According to this source, the states with the highest number of incubators classified as basic or traditional were the Mexico City of 23 incubators, Hidalgo, Jalisco and Sinaloa with 10, while Chihuahua, Nuevo León, Sonora and Veracruz had 8 each.

In Nuevo León the 8 incubators remain in operation maintaining their goal to "accelerate business growth and success through business support including physical spaces, access to funding, coaching and creation of business relations" (Albort \& Ribeiro, 2015, page. 1776)

Thus, the goal of this research is to analyze, from a theoretical perspective, the factors in the incubation process that enable the entrepreneur to have a competitive business advantage, for which the hypothesis proposed includes 4 the following independent variables: Coaching, business relations, digital social media, and entrepreneur profile. The dependent variable is business success. The theoretical foundation is described below.

\section{Theoretical foundation}

As mentioned in the introduction to this article, the importance of business incubators lies in the support they provide the entrepreneur through services. The National Association of Innovative Entrepreneurship Sponsoring Entities (2017) defines them as entities that offer entrepreneurs the support for transforming innovative ideas into successful ventures, with said success serving as support for the financial development of countries.

\section{Business success factors within business incubators}


Incubator

According to Theodorakopoulos (2014), the first generation of business incubators is based on offering low-cost shared spaces to support new ventures. The globalization of the economy makes it necessary for entrepreneurs to not only search for physical spaces but also receive counseling for their business projects, thus establishing the second generation of incubators between the years of. The current generation "brings business assistance for the development of business plans; assesses the technical, financial, and market viability of projects; provides physical and administrative spaces, logistics, information, and technical support services"(Mexico Emprende, 2016). It is in this last generation where the importance of incubators has reached its highest point, since they are not only work spaces for entrepreneurs but also physical locations where entrepreneurs develop their business projects alongside the business incubator; thus, it is a fundamental part of business success.

\title{
Business success (competitive advantage)
}

The term business success can be highly ambiguous in practice, since there are different ways to measure it; its analysis has covered dimensions such as decision-making capabilities, educational level, work experience, capacity to engage, creativity, increase in personnel, profit generation and/or business unit survival, and the individual's behavior as success factors (Korunka, Kessler, Frank, \& Lueger, 2010; Simpson, Tuck, \& Bellamy, 2004; Dafna, 2008). For this reason and for the purpose of this research, business success is to be understood as business continuity (Simpson, Tuck, \& Bellamy, 2004; Korunka, Kessler, Frank, \& Lueger, 2010). Based on financial and nonfinancial performance (Boniface, Gyau, \& Stringer, 2012), with financial performance being the increase in sales and non-financial performance being the increase in personnel.

According to applied studies, it is possible to consider the analysis of the impact of factors such as business relations, coaching, social media, and the entrepreneur's profile on business success in the context of business incubators (Watson, Hogarth-Scott, \& Wilson, 1998; Pinho \& Sampaio de Sá,

\author{
Landeros, C.; Terán, M. \& Blanco, M.
}


2014; Vidal Salazar, Ferrón Vílchez, \& Cordón Pozo, 2012), thus immediately commencing the study of each mentioned variable.

\section{Coaching}

Coaching it has served as a technique for meeting pre-established personal or business goals (Rekalde, Landeta \& Albizu, 2015), however, its primary significance is associated with its effect on entrepreneurs, since it can be an accelerator for the success of the entrepreneurial process. Zeus \& Skiffington (2002) defines it as a process wherein the coach and coaches work together to meet the established objectives. This way, the coach coordinates the handling of the action plan in order for coaches to receive the necessary support for personal and professional growth.

Generally, coaching is a method for assisting entrepreneurs to learn through the coach's experience; thus, it is a process of support and encouragement through a Socratic method, meaning, a way to drive the individual to search for and find solutions (Vidal Salazar, Ferrón Vilchez, \& Cordón Pozo, 2012).

Applied studies have shown different connections with improvement in business performance (Nuñez-Cacho Utrilla \& Grande Torraleja, 2013; Crompton, Smyrnios, \& Bi, 2012; Vidal Salazar, Ferrón Vílchez, \& Cordón Pozo, 2012).

\section{Business relations}

Business relations help develop a contact system within and outside organizations, enabling the generation of information that allows competitive advantage in international markets (Rahman Faroque, Morrish, \& Shahriar Ferdous, 2017). According to O'Donnell et al., (2001), these relations, are "a series of direct and indirect agreements, and the interaction of an individual with one or more individuals" (O'Donnell, Gilmore, Cummins, \& Carson, 2001, pág. 753). It is also established as a way to do business and a support process for decision-making through the confirmation and corroboration of information with third parties.

\section{Business success factors within business incubators}


Several authors have evidenced the importance of business relationships for entrepreneurs, since they enable the generation of collective knowledge gained by entrepreneurs, who use it in their favor to build a new business entity (McAdam \& Marlow, 2008). Pinho \& Sampaio de Sá (2014). identifies that relations play an important role in the entrepreneurial process, because they join entrepreneurs and organizations together, establishing positive ties that contribute to the growth of small businesses.

The foregoing gives us the possibility to increase knowledge through the analysis of the variable in a Mexican environment, which lacks said studies.

\section{Digital social media}

"With the arrival of web 2.0 the so-called new generation of internet users, social interaction rules have been rewritten, as well as the way to conduct business," (Van Zyl, 2009, pág. 906), as shown by the following data: $83 \%$ of workers in United States access social media through office resources and $30 \%$ of the workers in the United Kingdom use social media for issues related to their work (Van Zyl, 2009). The importance lies not only in the accelerated growth of this media in recent years but also in its use by businesses to cover their lack of institutional marketing and use of traditional media (Acquaah, 2011). A web 2.0 It is a way to describe communicational and informational technology applications based on the Internet, which aid in the communication, cooperation, and connection between users (Barnes, y otros, 2012).

The use of different social media programs by businesses has been related to their business success, which is why their analysis is important for this study. Social media can be defined as the "practice of expanding commercial and/or social contacts making individual connections through groups based the creation and exchange of contents of their creation" (Boling, Burns, \& Dick, 2014, pág. 123) for the benefit of the business (Pereira Correia, García Medina, González Romo, \& Contreras-Espinosa, 2014, pág. 299).

Applied studies have made efforts to find connections between digital social media and business success, as established by, who indicates a positive and significant relationship between the two.

Landeros, C.; Terán, M. \& Blanco, M. 


\section{Entrepreneur profile}

In recent years, entrepreneurs have become important due to the fact that they are the main architects of success, since their paths are directly associated with it. For this reason, interest for the expansion of knowledge related to the social and psychological characteristics of entrepreneurs has been growing. Therefore, several studies focus on the identification of the characteristics that serve to predict the success of entrepreneurs in their initial stage. Their efforts have provided results, obtaining factors such as personal characteristics, context of the business environment, business context surrounding the entrepreneur, and establishment of goals, to name a few (Chatterjee \& Das, 2015; Green, David, Dent, \& Tyshkovsky, 1996; Moriano, Trejo, \& Palací, 2001).

Caliendo \& Kritikos (2008) mentions that the characteristics supporting entrepreneurs toward their business success are need for achievement, position of control, need for autonomy, guidance toward problem-solving, tolerance to ambiguity, propensity to take risks, assertiveness, and interpersonal reactivity.

The importance for incubators to know the profiles of the entrepreneurs participating in their incubation programs lies in the necessity to expand the knowledge of their unique characteristics. This early identification helps business incubators in the design of specific support programs for entrepreneurs.

\section{Methodology}

This is a descriptive research, which employs the documental technique to review articles and magazine databases that support the theoretical framework. The type of research is quantitative because it attempts to measure the reliability of the proposed tool through the administration of 30 surveys. The study subjects of the research will be the owners or representatives of the companies trained and created through a business incubator in the state of Nuevo León. Moreover, only companies classified as micro, small, or medium enterprises by the Law for the Competitive Development of Micro, Small and Medium Enterprises in effect will be considered.

\section{Business success factors within business incubators}




\section{Results}

The tool's reliability analysis was carried out with the assistance of SPSS in its 24 version. The Cronbach's Alpha was used to obtain the reliability coefficient, which is an "index used to measure the internal consistency of a scale" (Celina Oviedo \& Campo Arias, 2005, pág. 575). Said coefficients are presented from 0 to 1 , where a value close to one would present a high correlation between the items presented in the measured construct, concept, or factor; in other words, they correctly measure what is intended to be measured (Celina Oviedo \& Campo Arias, 2005).

Having obtained data through the administration of the proposed measurement tool, variable $Y$ "Business success" shows a .785 with 5 elements in the construct. Item elimination is not necessary, since the elimination of any item decreases the factor's value (see table \#1).

Table 1. Reliability Statistics for And Business Success Alfa de Cronbach basada en

\begin{tabular}{lll} 
Alfa de Cronbach & elementos estandarizados & $\mathrm{N}$ de elementos \\
\hline .785 & .793 & 5 \\
\hline
\end{tabular}

Source: Own elaboration from collected data.

For variable 1 , containing 12 items, is obtained a .880 Alfa of Cronbach. No items are eliminated since the elimination of any question decreases the alpha value (see table \# 2).

Table 2. Reliability Statistics for variable $X_{1}$ Coaching Alfa de Cronbach basada en elementos

\begin{tabular}{cll} 
Alfa de Cronbach estandarizados & $\mathrm{N}$ de elementos \\
\hline .880 & .880 & 12
\end{tabular}

Source: Own elaboration from collected data.

Variable 2, Business Relations, has 8 items within the construct and casts an initial .828 Alpha factor of. The elimination of 1 item is found to increase factor a .840; thus, it is eliminated. A new run of a-factors Alfa is carried out, detecting that the elimination of the last factor increases the .849; thus, it is carried out once again. Upon new validation of the factors, no

\section{Landeros, C.; Terán, M. \& Blanco, M.}


improvement of said factors is detected and the final construct is composed of only 6 items and alfa of .849 (see table \#3).

Table 3. Reability Statistics for $X_{2}$ Business relations

Alfa de Cronbach basada en elementos

\begin{tabular}{lll} 
Alfa de Cronbach & estandarizados & N de elementos \\
\hline .849 & .851 & 6
\end{tabular}

Source: Own elaboration from collected data.

Construct $\mathrm{X}_{3}$, established as digital social media, has 6 initial items and shows an Alpha factor of .826. The elimination of question 6 helps raise factor a, .864 and so it is eliminated. When verifying the factors again, it is detected that the elimination of the 4 question helps increase factor .866; thus, it is eliminated. The new factors show that it is no longer possible to obtain a higher Alpha factor, thus the Alpha factor for the construct is set at .866 with a 4 total of items (see table 4).

Table 4. Reability Statistics for $X_{3}$ Digital Social Medias Alfa de Cronbach basada en elementos

Alfa de Cronbachestandarizados $\mathrm{N}$ de elementos

\begin{tabular}{lll}
\hline .866 & .869 & 4 \\
\hline
\end{tabular}

Source: Own elaboration from collected data.

Lastly, the results for variable $\mathrm{X}_{4}$, Entrepreneur Profile, has a total of 19 items and an initial Cronbach's Alpha of .890 , which is why no items are eliminated in the construct, since its reliability is guaranteed.

\section{Discussion}

There is a significant theoretical framework related to the issue of entrepreneurship, and this article shows the theoretical justification that enabled the elaboration of the tool. This theoretical justification enables to provide it with content validity. Once the theoretical justification was obtained, a review of the 46 tool's reliability was required, according to the Alfa factors, enabling us to obtain a final survey with questions structured in the following way. 5 items belonging to the dependent variable set as business success, 12

\section{Business success factors within business incubators}


more elements for the Coaching construct, 6 for the Business relation variable, 4 for Digital social media, and 19 more for the construct corresponding to Entrepreneur profile.

The results obtained through the alpha factors of Business success $(Y)$ .785 , Coaching $(X 1) .880$, Business relations $(x 2) .849$, Digital social media (X3) .866, and Entrepreneur profile (X4), .890 constructs show a reliable measurement tool for administration.

Therefore, the importance of this article is that it offers a measurement tool that can be used in research analyzing the factors proposed in this survey without limiting itself to issues regarding business incubators. The next step in this research is to complete the sample with a larger number of entrepreneurs and company representatives in order to establish the correlation of the proposed variables with business success using statistical regression.

\section{References}

Acquaah, M. (2011). Business strategy and competitive advantage in family business in Ghana: The role of social networking relationships. Journal of Developmental Entrepreneurship, 103-126.

Albort, G., \& Ribeiro, D. (2015). A bibliometric analysis of international impact of business incubators. Journal of Business Research, 1775-1779.

Asociación de Entidades Promoteoras de Emprendimientos Innovadores (2017). Preguntas frecuentes. Disponible en: http://anprotec.org.br/site/menu/incubadoras-eparques/perguntas-frequentes/

Barnes, D., Clear, F., Dyerson, R., Harindranath, G., Harris, L., \& Rae, A. (2012). Web 2.0 and micro-businesses: an exploratory investigation. Journal of Small Business and Enterprise Development, 687-711.

Barrientos Inostroza, M. (2016). Incubadoras de negocio ¿Son un aporte al emprendimiento en concepción? Horizontes Empresariales, 49-60.

Boling, R., Burns, M., \& Dick, G. (2014). Social networking and small business: an exploratory study. Contemporary Readings in Law and Social Justice, 122-129,

Boniface, B., Gyau, A., \& Stringer, R. (2012). Linking price satisfaction and business performance in Malaysia's dairy industry. Asia Pacific Journal of Marketing and Logistics, 288-304.

Caliendo, M., \& Kritikos, A. (2008). Is entrepreneurial success predictable? An ex-ante analysis of the character-based approach. Kyklos, 189-214.

Celina Oviedo, H., \& Campo Arias, A. (2005). Aproximación al uso del coeficiente alfa de Cronbach. Revista Colombiana de Psiquiatría, 572-580.

Landeros, C.; Terán, M. \& Blanco, M. 
Chatterjee, N., \& Das, N. (2015). Key psychological factors as predictors of entrepreneurial success: a conceptual framework. Academy of Entrepreneurship Journal, 102-114.

Comisión Nacional para la Protección y Defensa de los Usuarios de Servicios Financieros (2019). Educación financiera. Disponible en: https://www.condusef.gob.mx/Revista/index.php/usuario-inteligente/educacionfinanciera/492-pymes

Crompton, B., Smyrnios, K., \& Bi, R. (2012). Measuring the influence of business coaching on fast-growth firms. Small Enterprise Research, 16-31.

Dafna, k. (2008). Managerial performance and business success: Gender differences in Canadian and Israeli entrepreneurs. Journal of Enterprising Communities: People and Places in the Global Economy, 300-331.

Gibson, C., Jay, H., Hardy III, M., \& Buckley, R. (2014). Understanding the role of networking in organizations. Career Development International, 146-161.

Green, R., David, J., Dent, M., \& Tyshkovsky, A. (1996). The Russian entrepreneur: a study of psychological characteristics. International Journal of Entrepreneurial Behavior \& Research, 49-58.

Guceri-Ucar, G. \&. (2016). Exploring business incubation practices and relationships to drivers of start-up success in Turkey. International Journal of Entreprenerushio and Innovation Management.

Instituto Nacional del Emprendedor (2018). Reconocimiento. Disponible en: https://reconocimiento.inadem.gob.mX/

Inge Jenssen, J., \& Arent, G. (2002). Does the degree of redundancy in social networks influence the success of business. International Journal of Entrepreneurial Behavior \& Research, 254-267.

Instituto Nacional de Estadística y Geografía. (2019). Producto Interno Bruto. Disponible en: https://www.inegi.org.mx/temas/pib/

Joyce, P., Woods, A., \& Black, S. (1995). Networks and partnerships: managing change and competition. Small Business and Enterprise Development, 11-18.

Korunka, C., Kessler, A., Frank, H., \& Lueger, M. (2010). Personal characteristics, resources, and environment as predictors of business survival. Journal of Occupational and Organizational Psychology, 1025-1051.

Mayer Granados, E., \& Jiménez Almaguer, K. (2011). Las incubadoras de negocios en México: un análisis descriptivo. CienciaUAT, 8-13.

McAdam, M., \& Marlow, S. (2008). A preliminary investigation into networking activities within the university incubator. International Journal of Entrepreneurial Behavior \& Research, 219-241.

México Emprende (2016). Incubadoras de Empresas. Disponible en: https://www.mexicoemprende.org.mx/incubadoras-de-empresas/

Moriano, J. A., Trejo, E., \& Palací, F. J. (2001). El perfil psicosocial del emprendedor: un estudio desde la perspectiva de los valores. Revista de Psicología Social, 229-242.

Nuñez-Cacho Utrilla, P., \& Grande Torraleja, F. Á. (2013). The importance of mentoring and coaching for family business. Journal of Management and Organization, 386-404.

\section{Business success factors within business incubators}


O'Donnell, A., Gilmore, A., Cummins, D., \& Carson, D. (2001). The network construct in entrepreneurship research: a review and critique. Management Decision, 749-760.

Pereira Correia, P., García Medina, I., González Romo, Z. F., \& Contreras-Espinosa, R. S. (2014). The importance of Facebook as an online social networking tool for companies. International Journal of Accounting \& Information Management, 295-320.

Pinho, J. C., \& Sampaio de Sá, E. (2014). Personal characteristics, business relationships and entrepreneurial performance, some empirical evidence. Journal of Small Business and Enterprise Development, 284-300.

Pinho, J. C., \& Sampaio de Sá, E. (2014). Personal characteristics, business relationships and entrepreneurial performance, some empirical evidence. Journal of Small Business and Enterprise Development, 284-300.

Rahman Faroque, A., Morrish, S., \& Shahriar Ferdous, A. (2017). Networking, business process innovativeness, and export performance: the case of South Asian low-tech industry. Journal of Business \& Industrial Marketing, 864-875.

Rekalde, I., Landeta, J., \& Albizu, E. (2015). Determining factors in the effectiveness of executive coaching as a management development tool. Management Decision, 16771697.

Simpson, M., Tuck, N., \& Bellamy, S. (2004). Small business success factors: the role of education and training. Education + Training, 481-491.

The Global Entrepreneurship and Development Institute. (2018). The Global Entrepreneurship and Development Institute. Disponible en: https://thegedi.org/

Theodorakopoulos, N., Kakabadse, N., \& McGowan, C. (2014). What matters in business incubation? A literature review and a suggestion for situated theorising. Journal of Small Business and Enterprise Development, 602-622.

Van Zyl, A. S. (2009). The impact of Social Networking 2.0 on organisations. The Electronic Library, 906-918.

Vidal Salazar, M. D., Ferrón Vílchez, V., \& Cordón Pozo, E. (2012). Coaching: an effective practice for business competitiveness. Competitiveness Review: An International Business Journal, 423-433.

Vidal Salazar, M. D., Ferrón Vílchez, V., \& Cordón Pozo, E. (2012). Coaching: an effective practice for business competitiveness. Competitiveness Review: An International Business Journal, 423-433.

Watson, K., Hogarth-Scott, S., \& Wilson, N. (1998). Small business start-ups: success factors and support implications. International Journal of Entrepreneurial Behavior \& Research, 217-238.

Zeus, P., \& Skiffington, S. (2002). The coaching at work toolkit: a complete guide to techniques and practices. Sydney: McGraw-Hill. 